\title{
Bridging versus Bonding Social Capital in Entrepreneurs' Networks: The Case of Post-Conflict Western Balkans
}

\author{
Ana Kopren ${ }^{1, *}$ and Hans Westlund ${ }^{2,3}$ \\ 1 Faculty of Law, University of Graz, 8010 Graz, Austria \\ 2 KTH Royal Institute of Technology, SE-100 44 Stockholm, Sweden; hans.westlund@abe.kth.se \\ 3 Jönköping International Business School, Jönköping University, SE-551 11 Jönköping, Sweden \\ * Correspondence: anakopren7@gmail.com
}

check for updates

Citation: Kopren, A.; Westlund, $\mathrm{H}$. Bridging versus Bonding Social Capital in Entrepreneurs' Networks: The Case of Post-Conflict Western Balkans. Sustainability 2021, 13, 3371. https://doi.org/10.3390/su13063371

Academic Editor: Elisa Ughetto

Received: 11 February 2021

Accepted: 12 March 2021

Published: 18 March 2021

Publisher's Note: MDPI stays neutral with regard to jurisdictional claims in published maps and institutional affiliations.

Copyright: (c) 2021 by the authors. Licensee MDPI, Basel, Switzerland. This article is an open access article distributed under the terms and conditions of the Creative Commons Attribution (CC BY) license (https:// creativecommons.org/licenses/by/ $4.0 /)$.

\begin{abstract}
This article examines the value and effect of social capital deriving from cross-ethnic business cooperation on social networks and society in the aftermath of war. The study contributes to a deeper understanding of the social function entrepreneurship conveys beyond its economic role. Based on Putnam's bridging and bonding social capital theory and Granovetter's theory on weak ties, the article studies ties between entrepreneurs originating from different ethnic groups in ethnically divided post-conflict societies. This study highlights the capacity of entrepreneurs to produce and generate social capital across ethnic lines. The field study includes surveys and interviews in Bosnia and Herzegovina, Kosovo, and North Macedonia. The results show that the majority of entrepreneurs cooperate and employ across ethnic lines. Cross-ethnic business relationships formed between entrepreneurs create benefits not only for entrepreneurs but also for building social capital across ethnic lines, thus forming valuable, yet depleted, social capital in post-conflict societies. Voluntary relationships between managers and business owners set a valuable model of weak ties facilitating associative behaviour among divided ethnic groups. Business exchange and relationships create social values that transcend a simple financial transaction. Value is in the form of friendship and trust, a reliance that maintains entrepreneurs' relationships and contributes to the social capital.
\end{abstract}

Keywords: cross-ethnic cooperation; entrepreneurs; bridging; bonding; social capital; business networks

\section{Introduction}

In the aftermath of armed conflicts in the 1990s, post-conflict societies in the Western Balkans had a challenging task to re-establish favourable political and socio-economic conditions, amidst ethnic divisions. Ethnic boundaries are not as territorial, as much as they are social [1]. Thus, ethnic groups' organisations imply norms and values [1]. According to Van Dyke [2] (p. 344), "an ethnic community is a group of persons, predominantly of common descent, who think of themselves as collectively possessing a separate identity based on race or shared cultural characteristics, usually language or religion". Differentiating others as members of different ethnic groups implies recognition of limitations in shared understandings, distinct norms and values, and interaction restricted to sectors of implicit common knowledge and shared interests [3] (p. 15).

Eriksen [1] claims that the identity of ethnic groups is shaped in interaction with other ethnic groups. Ethnic relations are defined through the perception that ethnic groups have about themselves in their cultural distinctiveness and how they perceive other groups [1]. The post-WW2 government of Yugoslavia placed high expectations on the socialist ideology as the ultimate solution for socio-economic inconsistencies in society, eradication of national sentiments, and for the decline of unemployment.

However, the lack of common identity is one of the reasons for the dissolution of Yugoslavia [4]. Bieber [5] (p. 276) denotes that "the economic crisis after Tito's death contributed greatly to the revival of nationalism in Yugoslavia since the mid-1980s". The eco- 
nomic crisis advanced the proliferation of national tendencies in defending the right to self-determination. National political leaders were using nationalistic ideas for the political mobilization of people along ethnic lines [6] (p. 15). After the armed conflicts in the 1990s, ethnicity remains the dominant aspect of governance in post-conflict Western Balkans.

Bieber [7] (p. 90) notes that "ethnicity continues to be the primary political identity in most former conflict regions, especially in the more diverse parts of the former Yugoslavia, such as Bosnia-Herzegovina or Macedonia, ethnic affiliation often matters more than economic or social platforms". Despite significant progress in democratisation and reforms after dramatic conflicts in the former Yugoslav territories, ethnic divisions are deeply embedded in society.

Besides detrimental impacts on socio-economic conditions, violent conflicts have a devastating effect on social relationships. Violent conflicts within a state divide the population, decline social trust, and weaken social values that incentivise cooperation, tear social relationships, which altogether diminish society's social capital [8]. Social capital is critical to democracy [9], but it is a scarce resource in post-conflict societies. Diverse networks can act as a vital source of social capital for reconciliation and reconstruction in divided societies [8]. Colletta and Cullen [8] assert that awareness about the importance of increased social capital in post-conflict societies should supplement peace-building and reconciliation processes. Shared goals and interests nurtured through cooperative relations in economic associations across ethnic lines convey the significant potential for the reconstruction of fragile ethnic relations.

Economic ties created between entrepreneurs from different ethnic groups that have been on opposite sides in the conflict and their potential impact on facilitating social capital between ethnic groups are the central subject of this article. Entrepreneurs build and use social capital to expand business opportunities. Granovetter [10] was illuminating the importance of weak ties in business. We are emphasising the distinction of weak business ties formed in ethnically divided societies, and the social consequences of the bridging social capital (see Section 1.2) they produce.

The purpose of this article is to fill the gap in studies about business cooperation between divided ethnic groups in the Western Balkans, with a focus on Bosnia and Herzegovina (BiH), Kosovo, and North Macedonia. Business networks generate societal advantages that have not received sufficient attention in studies of post-conflict areas. We analyse the facilitation of social capital and social networks emerging from entrepreneurs' business relationships formed across alienated ethnic lines in post-conflict societies in the Western Balkans.

Increased interpersonal contact between members of groups in conflict incentivises mutual understanding and appreciation while reducing prejudices and discrimination [11]. Recurring business interactions contribute to breaking down prejudices and incentivise cooperative achievement between divided groups, thus increasing societal social capital. The magnitudes of social capital expand outside business domains once entrepreneurs circulate in their social environment.

\subsection{Social Capital and Entrepreneurship}

The interest in social capital has increased along with the understanding of its importance to economic development and overall social harmony in society. The American political scientist Robert Putnam made the concept known across the world in the mid1990s. Putnam et al. [12] (p. 1) define social capital as "networks, norms, and trust that enable participants to act together more effectively to pursue shared interests". Coleman [13] (p. 98) states that "social capital, like other forms of capital, is productive, making possible the achievement of certain ends that in its absence would not be possible". Social networks, norms, values, and trust are a valuable part of society's capital that is incentivising socio-economic development.

Bourdieu [14] considers relationships between various groups in the society that are embodied in preserving the interests of their members, be it ethnic, religious, or political 
groups. Bourdieu [15] (p. 51) reflects on the capacity of social capital, stating that "the volume of the social capital possessed by a given agent depends on the size of the network of connections he can effectively mobilise and on the volume of the capital (economic, cultural or symbolic) possessed in his own right by each of those to whom he is connected". The possession of the nodes that we can utilise enhances the productivity of our network, provided they are at our full disposal.

Social capital is a network attribute that resides in relationships and interactions among people $[12,13,16]$ that are governed by attitudes and values that enhance people's ability to join collective achievements and facilitate cooperation among groups [17,18]. Putnam defines social capital as "connections among individuals-social networks and the norms of reciprocity and trustworthiness that arise from them" [16] (p. 19). Westlund [19] (p. 1) provides a broader definition of social capital that encompasses relevant aspects of social capital: "social, non-institutionalised networks that are filled by the networks' nodes/actors with norms, values, preferences and other social attributes and characteristics".

Fukuyama [20] emphasises trust as the fundamental lubricant of social achievement. Reciprocity and trust maintain networks [21], while "trust facilitates social exchange" [22] (p. 113). Relationships based on mutual reliance and shared norms contribute to forming trust and bridging ties between networks. Trust is vital for restoring damaged social relationships after the conflict [8]. Higher stocks of social capital facilitate trusting relationships, which consequently have a positive impact on economic activities.

Portes [23] attributes social capital as a significant source of benefits gained through extra-familial networks. Furthermore, extra-familial relationships act as bridges between familial groups, such as ethnic groups, friends, and family. Insufficient stocks of bridging social capital can hinder the circulation of ideas, information, and resources between groups $[18,24]$. The ties that individuals create outside their familial groups connect closed systems.

The Putnamian notion of social capital as an attribute of civil society and community engagement has dominated social sciences [25]. Social capital is acknowledged in the form of volunteering activities, voting, neighbour relationships, and family and friendship relationships [26], but there is also social capital that is created and facilitated in business relationships [19]. Thus, social capital is not only a civic feature, but also generated and produced through other forms of associations, such as entrepreneurship.

Westlund and Bolton [27] claim that entrepreneurship is both a creator and the outcome of social capital. Westlund and Nilsson [28] (p. 1086) assert that "a small enterprise with spatially personal relationships has considerable incentives to build a strong social capital with the local environment". Social capital facilitated through business ties is a driving force of entrepreneurship.

However, social capital formed within certain groups and networks can work against community wellbeing. Coleman [13] asserts that social capital can be valuable in some actions, yet useless and damaging in others. Criminal organisations and other forms of associations gaining on the disadvantage of harming other social groups were identified by Putnam [16] as a negative externality. If the network is conducting activities that hurt other people, there may be positive externalities within the network but negative externalities toward society as a whole [29]. Consequently, social capital can also maintain social groups that harm others and spread discrimination and criminal activities. Therefore, social capital is not only created but can also be weakened and destroyed [17]. Privileged groups do not necessarily contribute to the public good, but to their own interests. Thus, social capital can also be counter-effective for the creation of social trust [17].

Portes [23] identifies several negative consequences that can derive from social capital: (a) exclusion of outsiders that may prevent cooperation with the other ethnic group, (b) community or group participation necessarily creates demands for conformity and entails social control, and (c) downward levelling norms that secure the discriminating status of members of other communities despite success stories of social interaction. Solidarity networks and strong social control within ethnic groups may lead to the exclusion of 
outsiders [23]. The exclusion of outsiders stipulates keeping the distance from the members of the other ethnic groups and disrupts the formation of bridging social capital.

\subsection{Bridging and Bonding Social Capital}

Social capital appears in the form of bridging and bonding social capital. Bonding social capital encompasses close and intimate "bonds" that people form with family and friends, and within ethnic and religious groups. Bridging social capital signifies external relationships formed with people belonging to different social groups, such as other organizations, firms, ethnicities, or religions.

Putnam [16] asserts that bonding social capital implies group loyalty. This loyalty might have negative external aspects when groups do not form strong relationships with other groups. Strong bonding social capital may disrupt bridging social capital. Closed groups are precautious to establish external connections that are significant for bridging divided groups.

Groups with strong bonding potential are inaccessible for friendly relationships with other ethnic groups in ethnically divided post-conflict societies. Westlund and Larsson [30] (p. 4) state that "barriers promote the emergence of bonding social capital, but obstruct the emergence of bridging social capital". Predominant bonding social capital may impede social cohesion.

Bonding social capital is an essential component of every group or organization, as is bridging social capital, without it, an organization devoid of bridging social capital would lack ties with the outside world [25]. Bonding and bridging capital are complementing firms' assets [25], so essentially, they are entrepreneurs' assets.

Depending on the type of relationships that dominate, Putnam [16] differentiates networks as bridging and inclusive, or bonding and exclusive. Inclusive networks direct towards cooperation, support, trust, and exclusive networks may support ethnocentrism and thus produce negative outcomes for society [16]. Putnam [31] points out that bridging social capital is harder to create than bonding social capital, but it is also the most essential for healthy public life in an increasingly diverse society.

However, Westlund and Larsson [30] underscore the need for balanced bonding and bridging social capital in development processes. Poulsen and Svendsen [32] assert that economic problems arise if the optimal balance between the shares of bridging and bonding trust in a society is disturbed by too much bonding trust without the presence of bridging trust as well.

The dichotomy of bonding/bridging social capital can be compared with the concepts of generalised versus particularised trust. Trust is a central component of social capital [12] and is often divided into generalised trust and particularised trust. The former refers to the trust that people have in other people in general. It is often measured in surveys, like the World Value Survey, with a question on whether the respondent thinks that most people can be trusted. Particularised trust is defined as "... the trust we place in specific individuals, such as family members, friends, and acquaintances" [33] (p. 319). The parallels between the two social capital concepts are obvious. Particularised trust is a strong component part of bonding social capital and enforces the bonds to the trusted, closest actors. Generalised trust is a prerequisite for extending the social capital outside the bonded circles and creating bridging social capital with actors "outside".

Here, we should also mention two other concepts of trust, viz. social and institutional trust, where the former often refers to trust in other people, both within the own group and outside it. Thus, social trust includes both particularised and generalised trust. Institutional trust refers to peoples' trust in institutions.

More occasions for collaborative action through business and social networks stimulate interaction and trust across ethnic groups. In her study of social capital in two Bosnian cities, Pickering [34] asserts that business interaction helps in raising bridging social capital. She established that social capital created through social networks in mixed workplaces might provide opportunities for repeated cross-ethnic interaction among colleagues of 
equal status and enable people to form relations of varied intimacy with colleagues of different ethnic backgrounds. Pickering [34] concludes that a mixed workplace is the most fertile environment for promoting cross-ethnic cooperation.

Pieterse [35] notices that ethnicity is observed from the perspective of differences, thus mostly examined as the bonding social capital and not as an opportunity for bridging social capital, which also explains why cross-cutting ties between ethnic businesses are under-researched. Pieterse [35] considers cross-ethnic relationships vital for the businessowners in immigrant communities. Entrepreneurs' need for labor, training, new clients, and supplies inevitably brings immigrant business owners in cooperation with a variety of networks [35].

In his empirical study, Tolciu [36] concluded that entrepreneurs are not bound to their ethnic group in business and that economic preferences to widen business networks motivate immigrant entrepreneurs to be open for business with native-born customers. Immigrants are attentive to the needs of their customers for which reason they employ workers of diverse ethnic structure to attract customers and clients different from their ethnic origin [36].

\subsection{Strong and Weak Ties}

Mark Granovetter instigated the analysis of social networks from the perspective of ties that contributors cultivate. Granovetter [10] differentiates relationships formed between individuals in the family, religious or ethnic groups as strong ties and relationships formed between distant individuals as weak ties. Weak ties enable bridges between networks [10,37], add to the diversity, and open the door to new opportunities [38].

Strong ties maintain the family networks, while weak ties enable bridges between family networks. Westlund and Larsson [30] (p. 3) assert that "shared norms and values may be stronger in strong ties, but social interaction in spatially concentrated weak links can also rely on shared norms and values, thus shaping social interaction in weak ties". Different subgroups that are otherwise divided connect through weak ties [10,39]. Weak ties have the potential to incentivise cooperative behaviours between groups.

However, Aldrich and Zimmer [40] claim that weak ties are not equally important, only those that provide access to social resources. The factor of closeness and the frequency of interaction distinguish strong from weak ties. While weak ties are useful when individuals seek valuable information outside their usual groups of contacts, strong ties are helpful for socio-emotional support [41]. The intensity and endurance of interpersonal relationships depend on the amount of time invested, emotional intensity, and reciprocal services [10].

Considering that maintained business relationships transform weak ties into strong ties [42] and that the strength of a tie is based on the amount of time and emotional intensity invested, Granovetter [10] implies that weak business ties may not be as weak. Friedkin [43] claims that the frequency of interaction may imply it is a strong tie, but an emotional basis that is inherent to strong ties might be missing.

Granovetter [10] asserts that weak ties are a vital element of social structures that integrate otherwise disconnected social clusters into wider society. Entrepreneurs' networks connect through weak ties, which provide access to valuable information and resources to manage their business. Social interactions arising from business exchange create weak ties between participants of the economic transaction. These ties have the potential to incentivise pro-social behaviours for their participants [44].

\subsection{Research Questions}

The primary objective of this article is to examine the effects of ethnically mixed business networks in divided post-conflict societies and to analyse factors that encourage or impede cross-ethnic forms of businesses. Further, we assess the impact of businessrelated social capital on societal social capital. This is done by answering the following research questions: 
- What factors explain the incidence of cross-ethnic cooperation and employment?

- What is the role of entrepreneurs' bridging and bonding relationships in facilitating social capital?

- What forms of cross-ethnic business networks exist?

Related studies focus on the impact of ethnic bonds on firms' economic performance, and the formation of social capital, again in the service of business and the economy, without considering the social implications of ethnically mixed business networks. We test the following hypothesis: entrepreneurs form bridges between ethnically diverse business networks, but different circumstances of various impacts counteract the formation of bridging social capital in ethnically divided post-conflict societies. Despite their willingness to network, entrepreneurs may be constrained to expand their market due to ethnic cleavages. In the struggle to preserve their firm, they are challenged to either follow their business acumen or follow the ethnic divisions in their countries.

\section{Materials and Methods}

Research Methods and Data

The foundation for bridging relationships between ethnic groups is the business relationship between entrepreneurs. Entrepreneurs establish a business relationship at the firm level—cooperation, and at the individual level—employment, which we postulate as two indicators of this study. Research methods included interviews, surveys, and analysis of statistical data.

Author 1 organised 10 semi-structured interviews with professionals responsible for designing and implementing policies in regional economic development and entrepreneurship in Bosnia and Herzegovina and Kosovo in September 2012 and North Macedonia in September 2014. Author 1 held interviews to estimate if there is cross-ethnic cooperation and in what form. The interviewees' confirmation that cross-ethnic business cooperation existed was vital for Author 1 to decide on extending the field research with entrepreneurs.

Author 1 conducted a closed survey with 130 entrepreneurs from 39 towns, including 50 entrepreneurs from $\mathrm{BiH}, 40$ from Kosovo, and 40 from North Macedonia. The survey was organised and implemented in August and September 2013 in $\mathrm{BiH}$ and Kosovo, and in September 2014 in North Macedonia. The response rate was approximately 95\%. The average age of entrepreneurs in the survey was 38.7 years. Entrepreneurs in the sample originated from six different ethnic groups: North Macedonians 24.6\%, Bosniaks 23\%, Albanians 23\%, Serbs 21.6\%, Croats 6.2\%, and Roma 1.6\% (Figure 1).

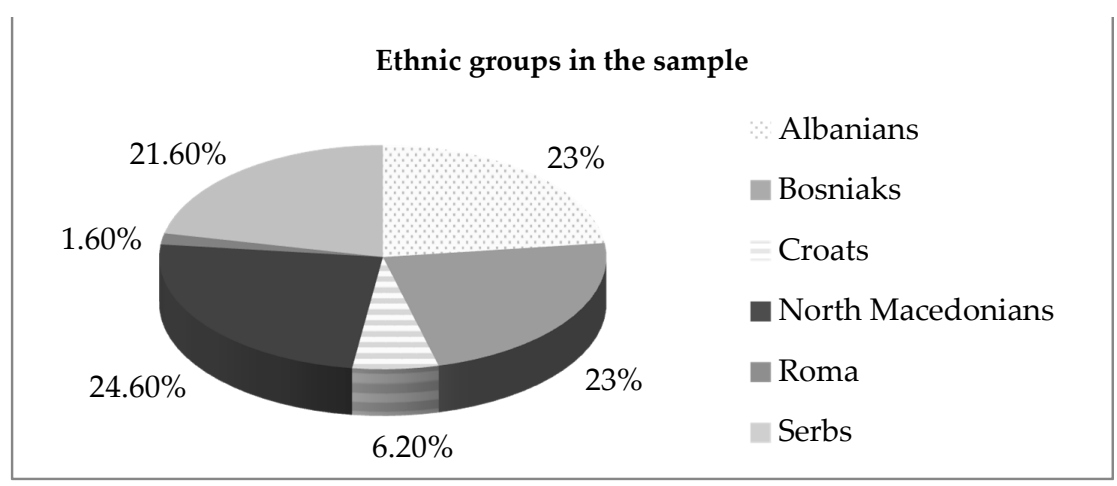

Figure 1. Ethnic groups in the sample.

Author 1 structured the representative sample aiming to, first, include all major ethnic groups that were directly involved in the armed conflict; second, cover diverse areas and different towns within one country; and third, include firms from dominating economic sectors. The representative sample of this research includes entrepreneurs from major ethnic groups in their active working age of both genders that work in trade, agriculture, construction, services, and tourism, as shown in Figure 2. 


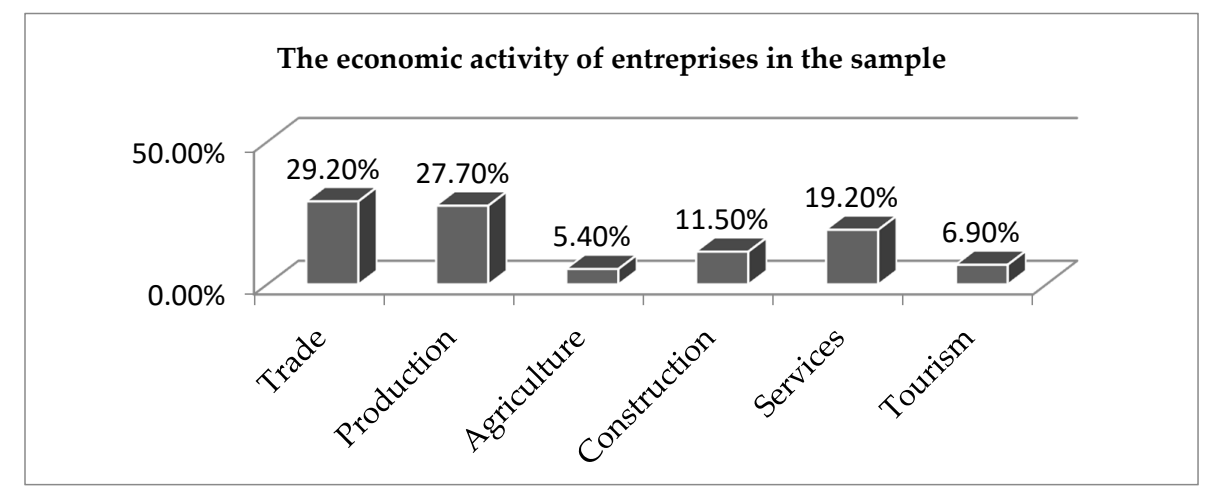

Figure 2. The economic activity of enterprises in the sample.

The sample includes small and medium-sized enterprises (SMEs) (Figure 3) privately owned by citizens of the countries where the survey took place. Given that entrepreneurs are embedded in their local communities, Author 1 only considered local SMEs, and not foreign multinational companies, public enterprises, or large private companies for this study. Cultural environment and connections at the local level may not be a determining factor in formulating business strategies in large national or international companies.

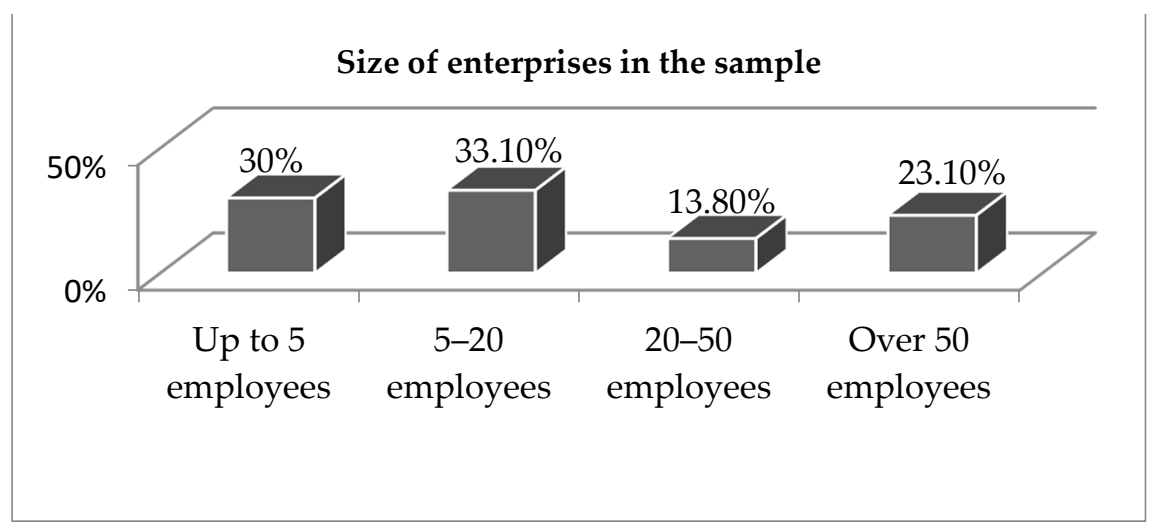

Figure 3. Size of enterprises in the sample.

The questionnaire included three sets of questions: (1) basic demographic data of entrepreneurs; (2) characteristics of enterprises; and (3) entrepreneurs' choice to cooperate with other ethnic groups, motivation, quality of cross-ethnic business relations, the inclination to employ, and benefits from employment. Considering the occurrence of ethnically mixed family lineages in the selected geographical areas, the ethnic group affiliation is self-defined by the entrepreneurs in the sample. The empirical data presented in this study are based on questions with discrete reply alternatives.

Author 1 applied the versatile approach to establish contact with entrepreneurs, either through interviewed professionals or directly. Managers in Regional Development Agencies in $\mathrm{BiH}$ and Macedonia provided the contact details of 20 entrepreneurs. Author 1 directly approached 110 entrepreneurs in their firms in BiH, North Macedonia, and Kosovo inviting them to share their opinion on the studied subject. Entrepreneurs had a face-to-face interview with Author 1 while responding to the survey. Survey results were analysed with descriptive statistics.

We used the statistical data about social and institutional trust in $\mathrm{BiH}$, Kosovo, and North Macedonia. Indicators for competitiveness and ranking of the functioning of the economic institutions, provided by the World Economic Forum, were calculated for $\mathrm{BiH}$ and North Macedonia, but excluded data for Kosovo. 


\section{Results}

The main question about cooperation was: "Is there cooperation with enterprises whose owners or managers originate from a different ethnic group?" The results show that $83.9 \%$ of the entrepreneurs engage in cross-ethnic cooperation, whereas $16.1 \%$ avoid cooperation across ethnic lines (Figure 4). The cooperation rate differs among the case studies, $92.5 \%$ in North Macedonia, $86 \%$ in $\mathrm{BiH}$, and $72.5 \%$ in Kosovo, as shown in Figure 4. Entrepreneurs working across ethnic lines designate cross-ethnic cooperation as very satisfying in $45 \%$ and good in $48.6 \%$.

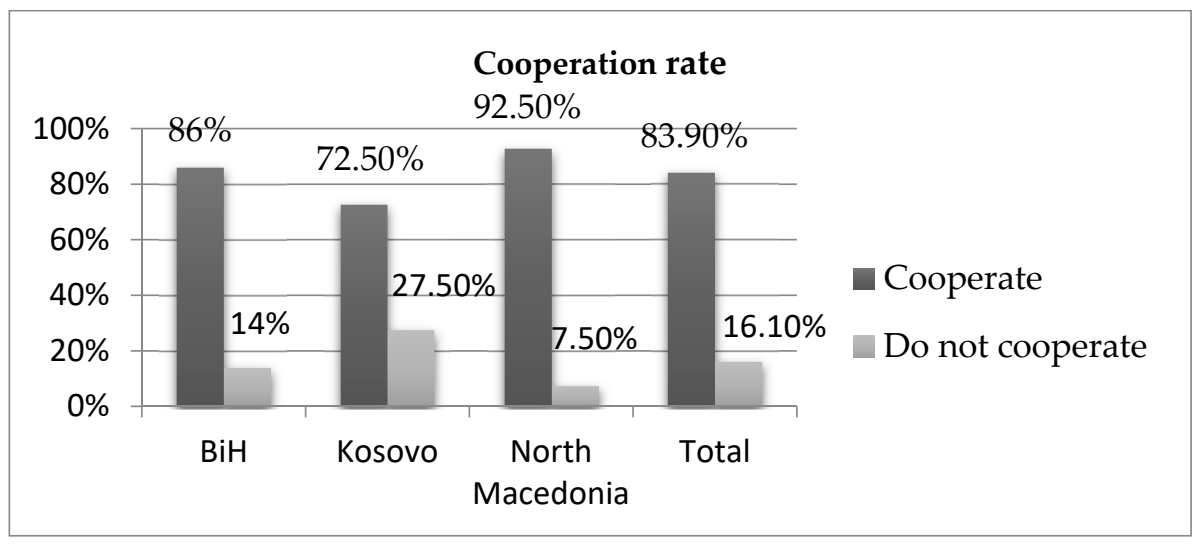

Figure 4. Cooperation rate in the sample.

Some entrepreneurs avoid business across ethnic lines or have tried but could not implement cooperation. The absence of cooperation is highest in Kosovo 27.5\% (Figure 5). In the overall sample, $55 \%$ of entrepreneurs that avoid cooperation are Albanians in Kosovo, while the remaining $45 \%$ came from other ethnic groups in the sample. Figure 5 shows the non-cooperating entrepreneurs divided into those who plan to cooperate but have not done it yet and those who abstain from cooperation. The ratio of rejecting cooperation is highest in Kosovo (Figure 5). That share is significantly lower in $\mathrm{BiH}$ and North Macedonia.

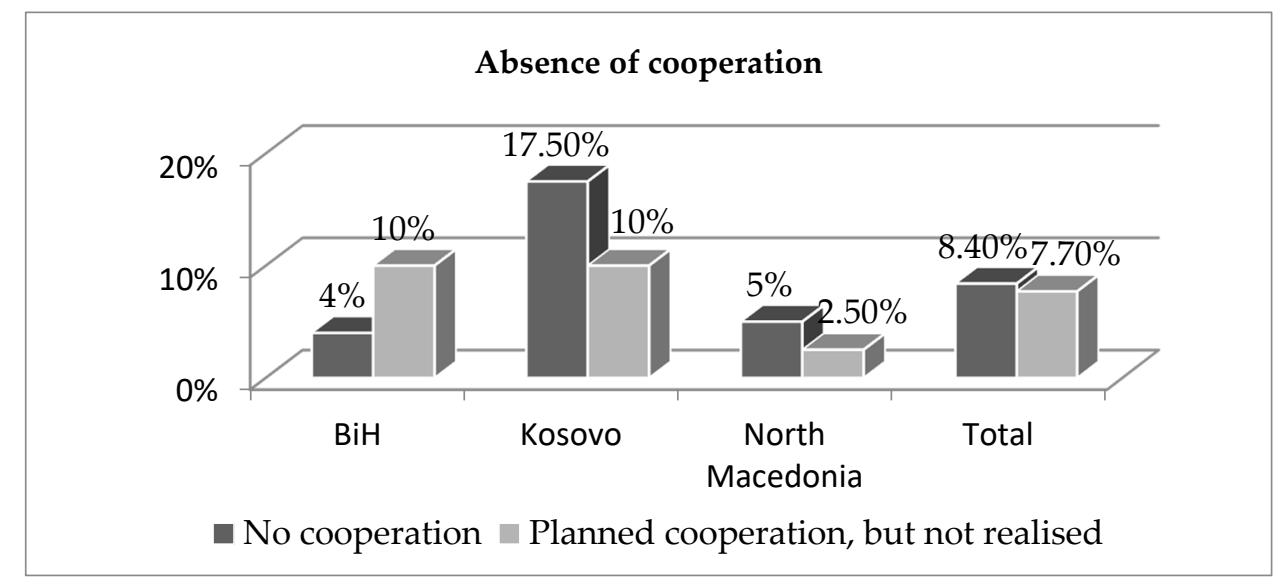

Figure 5. Absence of cooperation in the sample.

Results indicate that female entrepreneurs engage in cross-ethnic businesses more than men, $92.9 \%$ and $81.4 \%$, respectively. The difference between genders is lesser in inclination to employ, $89.1 \%$ for women and $86.1 \%$ for men. The findings distinguish that the same ethnic groups have variations in cooperation in different countries. Serbs in $\mathrm{BiH}$ are more involved in cross-ethnic businesses than Serbs in Kosovo. Albanians in North Macedonia have a higher cooperation ratio of $86 \%$, in comparison to $68.2 \%$ of cross-ethnic cooperation among Albanians in Kosovo. 
The decisive motivating factor for entrepreneurs to establish business across ethnic lines is profit followed by expansion of the business network (Figure 6). Entrepreneurs in North Macedonia chose good cooperation as the highest motivating factor, while in Kosovo, they favour the expansion of the business network and are searching for a better price, and in $\mathrm{BiH}$, entrepreneurs prefer to advance their position in the market (Figure 6).

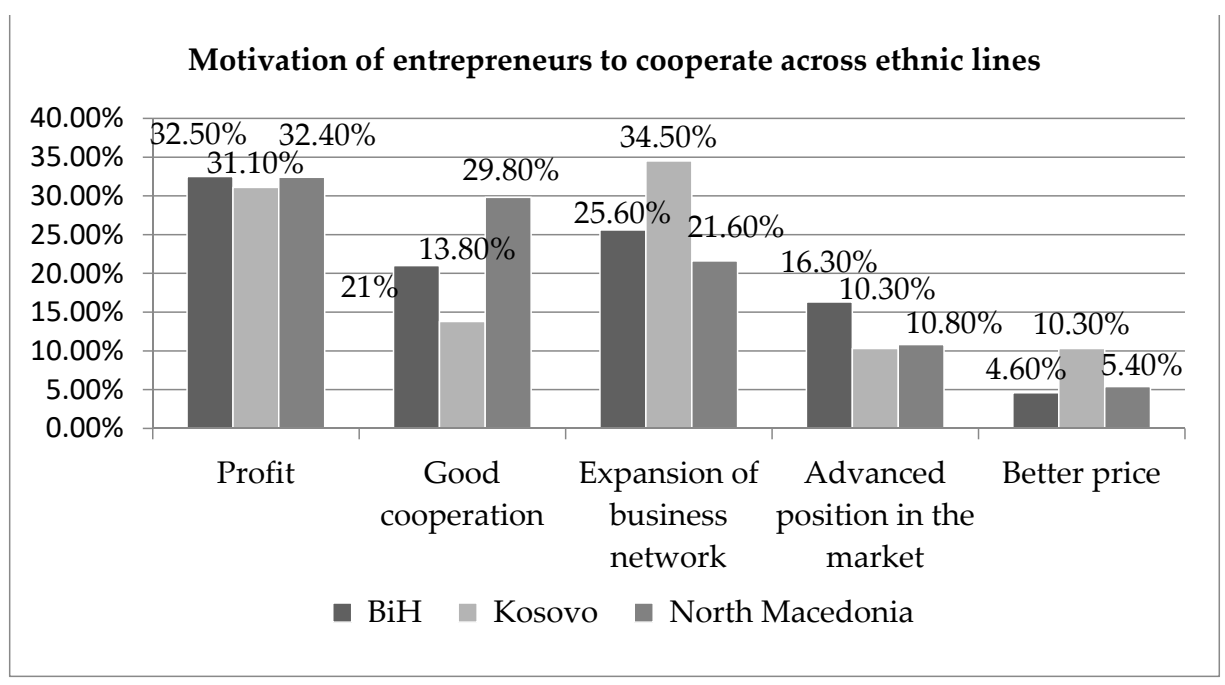

Figure 6. Motivation of entrepreneurs to cooperate across ethnic lines.

The main question about willingness to employ was: "Would you employ a person that originates from a different ethnic group?" This question tests the inclination of entrepreneurs to employ workers of an ethnic group other than their own, even if they live in mono-ethnic neighbourhoods. The readiness of business owners and managers to employ ethnically diverse workers and entrust them with working responsibilities is acceptable for $85.4 \%$ of entrepreneurs (Figure 7 ).

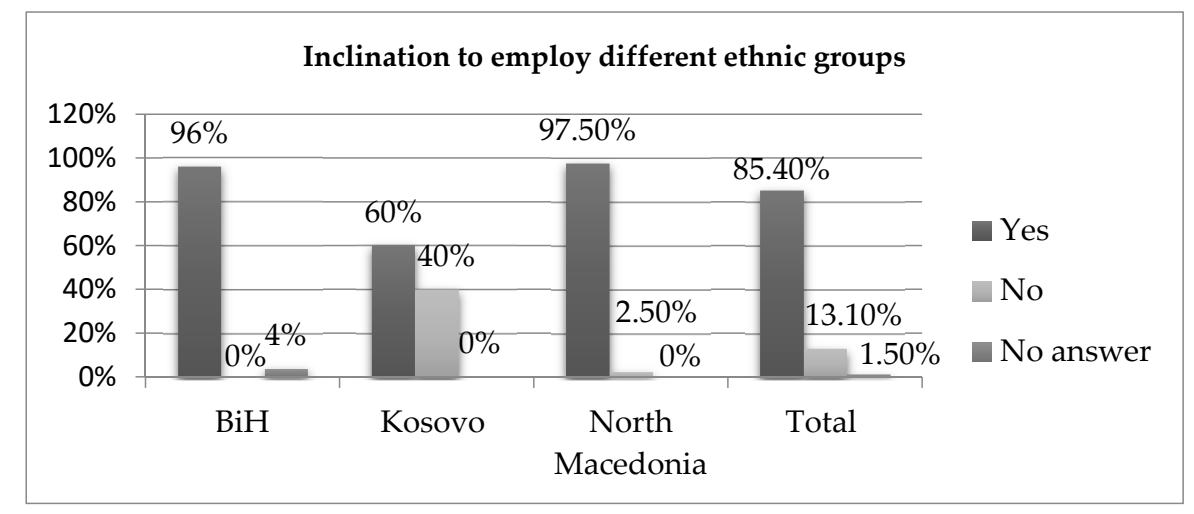

Figure 7. Inclination to employ different ethnic groups.

The absence of interest in involving other ethnic groups in the firm is most discernible in Kosovo, where $40 \%$ of entrepreneurs would not employ other ethnic groups. Results indicate that employers hiring employees of different ethnic origins is a common practice in North Macedonia (97.5\%) and in $\mathrm{BiH}(96 \%)$ but there is not as widespread an occurrence in Kosovo, with $60 \%$, as shown in Figure 7. On many occasions, entrepreneurs added that a worker's ethnic background is irrelevant for business, emphasizing the relevance of professional experience, skills, and reliability.

Entrepreneurs' awareness of the importance of extended networks incentivises employment across ethnic lines. The market expansion is the most distinguished benefit of cross-ethnic employment (Figure 8). In North Macedonia and BiH, the second prevalent 
reason is improved teamwork, whereas entrepreneurs in Kosovo prefer cultivating public relationships (Figure 8).

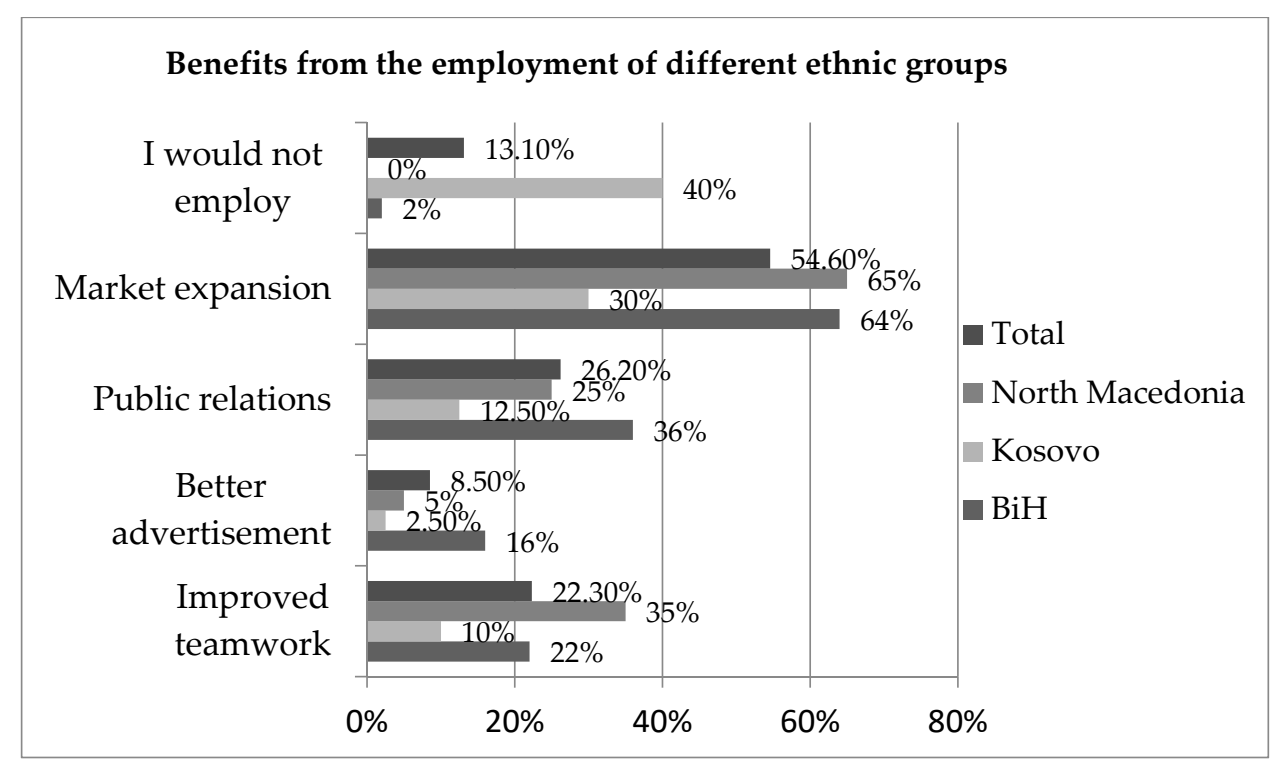

Figure 8. Benefits from the employment of different ethnic groups.

In Figures 9 and 10, data about cooperation and employment are segregated to responses of entrepreneurs in enterprises established before and after the wars ended. Entrepreneurs with firms established before the war have a higher propensity for cooperation across ethnic lines in North Macedonia and Kosovo but lower in the case of $\mathrm{BiH}$ (Figure 9). Entrepreneurs in North Macedonia and $\mathrm{BiH}$ with pre-war businesses display a $100 \%$ inclination to employ different ethnic groups (Figure 10).

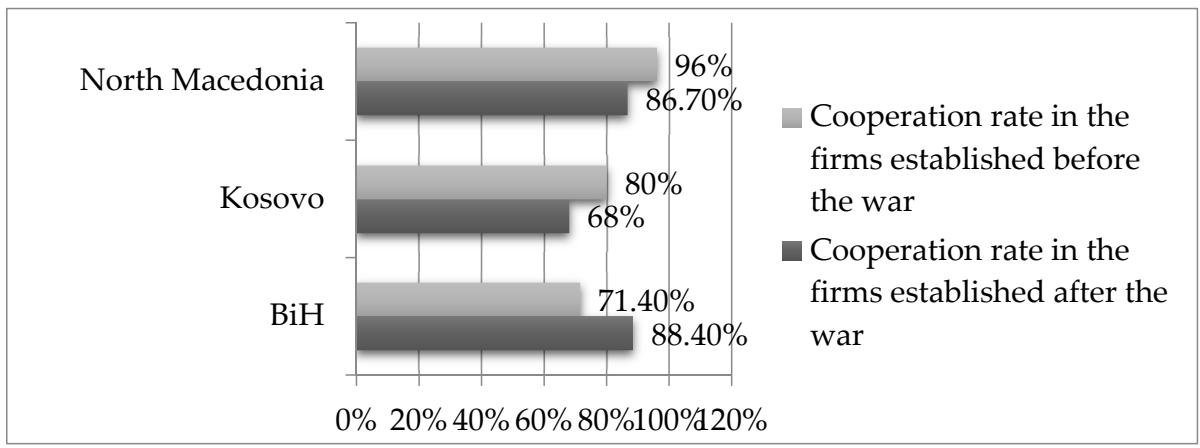

Figure 9. Cooperation in firms established before and after the war.

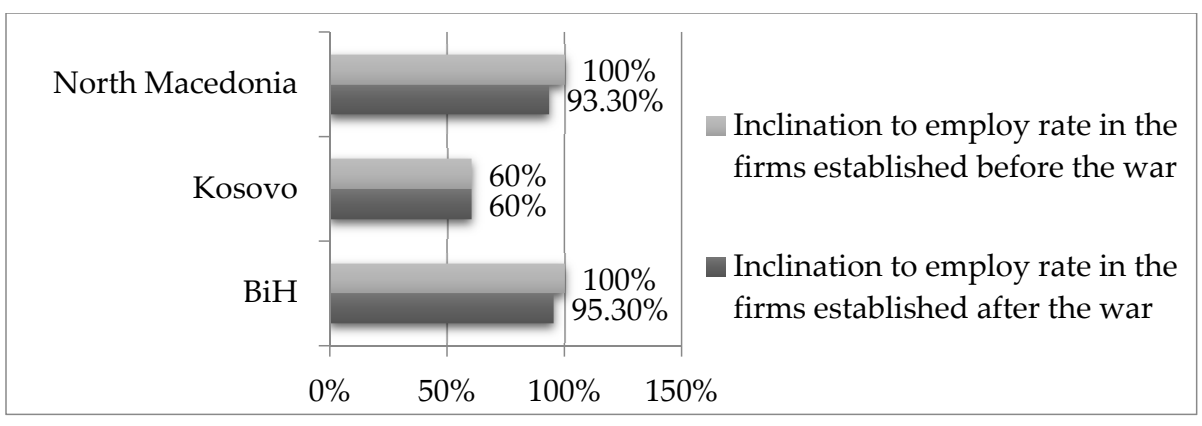

Figure 10. Inclination to employ in firms established before and after the war. 


\section{Discussion}

In this section, we discuss the evidence supporting the hypothesis that entrepreneurs build bridges between ethnic groups that are counteracted by different circumstances of various impacts in ethnically divided post-conflict societies. In the three subsections, we respond to each research question, respectively. Finally, we outline the evolution of ties from weak to strong and their strength in channelling exchange between ethnically diverse networks.

\subsection{Entrepreneurs' Bridging Social Capital}

Challenging socio-economic conditions accompanied by the lack of social and institutional trust create impediments but do not obstruct the creation of cross-ethnic bridging social capital, as indicated in the finding that $83.1 \%$ of entrepreneurs had cross-ethnic cooperation and $85.4 \%$ showed a willingness to employ labour from other ethnic groups. Cooperation is established by $92.5 \%$ of entrepreneurs in North Macedonia, $86 \%$ in $\mathrm{BiH}$, and $72.5 \%$ in Kosovo (Figure 4). Entrepreneurs would employ across the ethnic borders by $97.5 \%$ in North Macedonia, in $\mathrm{BiH} 96 \%$, and 60\% in Kosovo (Figure 7). Cross-ethnic cooperation is more pronounced among Albanians in North Macedonia than in Kosovo. Seemingly, the business environment is more supportive of cross-ethnic cooperation in North Macedonia and BiH than in Kosovo.

Several factors may explain the differences in shares of cooperation and employment. First, the legacy of conflicts inflicted severe conditions on society, second, the functioning of the economic regulatory framework, and third, the lack of institutional and social trust. The duration of the conflict, many fatalities, and the gravity of socio-economic and political consequences imposed more damage on $\mathrm{BiH}$ and Kosovo than in North Macedonia. North Macedonia was not required to invest as many resources and time in peace-building and economic recovery, as was the case in $\mathrm{BiH}$ and Kosovo.

In the time that $\mathrm{BiH}$ and Kosovo needed to recover after the large-scale violent conflict, North Macedonia invested in the development and alleviation of the consequences of the low-scale conflict. North Macedonia was involved in the process of European integration longer than the two other case studies. It has been receiving technical assistance for advancing entrepreneurship and economic development since the mid-1990s. Consequently, North Macedonia advanced in obtaining a support system for the SME sector in comparison to $\mathrm{BiH}$ (The Global Competitiveness Report ranks North Macedonia at 68 out of 138 countries, whereas BiH ranks 107 [45]. North Macedonia was positioned exceptionally high in comparison to the countries in the region in goods market efficiency, as the 34th out of 138 countries, while BiH ranks 129 [45]. North Macedonia is in second place in the world for the ease of opening SMEs [46].

Institutional and social trust is lower in Kosovo and $\mathrm{BiH}$ than in North Macedonia. Citizens in Kosovo display medium trust in international institutions and low trust in domestic political institutions [47,48]. Citizens of $\mathrm{BiH}$ and North Macedonia perceive that due to corruption and inefficiency, their political elites cannot be trusted as shown in empirical works of UNDP [49] and Marković and Damjanovski [50].

The deficiency of trust is twofold, people lack social trust, but there is an evident lack of trust towards institutions [51]. The study about social trust in $\mathrm{BiH}$ [52] demonstrates that $84.2 \%$ of citizens lack trust in others. In North Macedonia, 23.1\% of citizens trust others [50], and $38.7 \%$ of respondents declared having trust in state institutions [53]. The trust in state parliament in $\mathrm{BiH}$ was $23.4 \%$, whereas trust in cantonal governments was $23.6 \%$ [54].

Social distrust and institutional distrust are correspondingly high. It would be difficult to estimate how much distrust towards institutions is reflected in the distrust of individuals towards people of either ethnicity. The assumption is that distrust in institutions and distrust among people are mutually reinforcing.

The absence of trust towards institutions promotes closer inward ties within families and ethnic groups that serve as the support system to supplement the institutional insufficiencies. Even though close ties hinder the formation of external relations with other 
ethnic groups, bonding relationships can be important for extending the social capital that entrepreneurs create in business networks.

The lower ratio of cross-ethnic cooperation and employment in Kosovo stipulate hostile circumstances for cross-ethnic alliances. Negotiations about the political status of Kosovo and occasional ethnic tensions nurture adverse factors for cross-ethnic cooperation. The governments of Kosovo and Serbia assume political positions that hinder conditions for cooperation among the local population, which makes it much more challenging to cultivate cooperative arrangements and boost beneficial bridging social capital.

Comparing cross-ethnic business cooperation ratios in this empirical study with institutional and social trust data indicates that citizens in $\mathrm{BiH}$ and North Macedonia place more trust onto their business associates of diverse ethnic origin than in their governments. In business affairs, the cross-ethnic bridging social capital is prevalent over bonding. Generating ties outside of the comfort zone of family and close friendships, and preparedness to form business associations with diverse ethnic groups is advancing the bridging potential of business ties.

\subsection{The Balance between Bridging and Bonding Social Capital}

A share of $16.1 \%$ of entrepreneurs in the survey is disinclined to form bridging relationships with entrepreneurs from other ethnic groups. Results in the Kosovo case study show the lowest share among the case studies in applied indicators of cross-ethnic cooperation and employment. In the Kosovo sample, $40 \%$ of entrepreneurs observe no benefits from the employment of other ethnic groups, which affirms difficulties in the creation of bridging relationships between Serbs and Albanians.

Bonding relationships presume loyalty and emotional closeness. The loyalty of an entrepreneur to his/her family, friends, and ethnic group may foresee the exclusion of the other ethnic groups from social interaction as verification of that loyalty. Excessive bonding social capital may disrupt the rise of bridging social capital.

The case of a Bosniak taxi driver in Sarajevo sets an example of an attempt of his friends to disrupt a bridging relationship. The Bosniak entrepreneur from Sarajevo described having supportive collaboration with Serbian colleagues who helped him to start his business. However, the driver's Bosniak friends did not support this cross-ethnic partnership and tried to discourage his cooperation with Serbs. The taxi driver resisted this intrusive bonding social capital.

While the Bosniak taxi driver is still connected to his family and friends, it is the relationships with Serbian colleagues-the bridging social capital that contributes to his business. The trust originating in the bridging relationships benefits the success of ethnically heterogeneous business networks. Whereas bonding relationships can, on the one side, impede bridging relationships, trust existing in bonding relationships may be the main conduit of trust that occurs within bridging business relationships. The trust from bridging relationships is further dispersed through bonding relationships.

Bonding trust from personal networks enhances the potential for the creation of bridging trust. Entrepreneurs could utilise bonding trust in transmitting information about achievements from business relationships formed across ethnic lines. Actors in bonding social relationships can spread affirmative information about cross-ethnic cooperation. For example, someone getting a job in a firm owned by a member of another ethnic group or sharing a positive impression about the ethnically mixed working environment, or starting a business due to information received through cross-ethnic channels.

An entrepreneur committed to his/her family can still be accessible for interaction and contact with clients and partners of different ethnic origins. In such a way, entrepreneurs create a balance between bridging and bonding social capital. A business owner may be inclined to prioritise close relationships with family members and friends, but as Granovetter [10] exerts, that may be disadvantageous for business. The formation of bridging relationships with diverse business networks in the market enhanced economic opportunities. 
However, the lack of cross-ethnic cooperation and employment hinders the formation of cross-ethnic ties, thus deteriorating bridging social capital. At the same time, channels and reciprocity that instigate trust from the cooperative relationships cannot develop, which disrupts liaisons between ethnic groups, thus encouraging divisions and segregation.

Cooperation and employment stimulate social capital across ethnic groups. While entrepreneurs form multi-ethnic partnerships and associations to increase productivity, they at the same time, create social capital. Entrepreneurs' business connections may intersect with the business owners' circle of friends and family. Intersection enables the flow of social capital between ethnically diverse business and personal networks.

\subsection{Inclusive, Exclusive, and Hidden Business Networks}

Business networks differ on the criteria of exclusivity and public exposure. Concerning the ethnic origin of their members, business networks appear in the form of inclusive, exclusive, and hidden networks. Ethnically heterogeneous business networks are inclusive networks, as they include members of various ethnic origins. Minorities are socially included through business engagement in the socio-economic transactions with the majority population.

Author 1 interviewed an Albanian owner of a dairy plant who shared his experience of satisfactory business relationships with minority Serbian cow and heifer breeders throughout Kosovo several years after the war in Kosovo in 1998-1999. Cooperation with the Serbian community started with an anecdote when Serbs approached him, asking if he would buy milk from Serbian cows. He responded that he was not aware the cow has a nationality, but even if it is of an Albanian or Serbian owner, it is only relevant if a cow gives good quality milk.

With the USAID assistance and credit loan, Serbian farmers bought 500 heifers. In cooperation with the Albanian owner of the dairy plant, farmers improved the nutrition of the cattle, thus enhancing the quality of milk and increasing their market. The collaboration led to the expansion of the network of cattle breeders and milk collectors, so a cross-ethnic alliance resulted in increased market and profit. A dairy plant collects milk from fifty Albanian and Serbian farmers throughout Kosovo. The owner of the dairy plant reports that he has excellent cooperation with Serbian cow and heifer breeders throughout Kosovo.

Seemingly, the lack of job opportunities and the geographical closeness joined with common attributes lead to the association of Albanian and Serbian dairy producers in a competitive business network. When people are living in proximity, they tend to work together, but remaining animosity may still preserve the exclusive networks. Business networks with inclusive features generate public good, but there can also be exclusive networks.

Business networks can be exclusive based on ethnicity or for the sake of securing a position in the competitive market. Businesspersons may experience exclusion and discrimination for reasons that are not related to the quality of their product and service. For example, buyers of one ethnic group may reject a product of a producer from the other ethnic group or exclude firm-owners of different ethnic origins from business networks. That was the case with a Serbian pastry producer in Gračanica (Kosovo), whose attempts to establish business cooperation with Albanian shop-owners and sell them his baked products fell short of success. The problems of the Serbian pastry producer multiplied due to the limited market, which lowered his income and created pressure to maintain stable profit and payments to his staff.

According to the Riinvest Institute study [55], Serbs hesitate to sell in Albanian communities because of barriers such as language and trust. Interviewee No. 10 gave an example of a Serbian business-owner who was asked not to come and sell in a dominantly Albanian populated village because of the competition and not because of his ethnic background. The public perceived this case as problematic because of ethnic connotation, and not due to the elimination of competition from the market (Interview 10). It is difficult to determine if the motivation was profit or ethnic discrimination. 
However, minorities will hardly maintain their businesses if customers and clients from the majority group reject to cooperate, and consequently decrease their profit and devastate their businesses. Rejection of cooperation or work generates an atmosphere of economic exclusion in the service of winning the competition in the market, thus sustaining ethnic segregation. The minority population has to cooperate with the majority population or face deterring effects on their firms, due to limited business opportunities within their ethnic group.

Marginalization is not necessarily founded only on diverse ethnic origins. Association of firms can restrict other firms from their network to defeat the competition. Firms may be connected to political authorities, which provide privileges for winning tenders and procurement contracts. Networks that are winning the market based on bonding ties with the political authorities are excluding rivalry firms. An exclusive club in this situation produces negative externalities, as they are suppressing firms without privileged connections in the market that may have a better-quality product.

Multi-ethnic business networks may also include entrepreneurs that gain advantage through favourable connection with the political elites. Bridging social capital can also maintain social networks that spread discriminatory and illegal behaviour in the market. Privileged groups do not necessarily contribute to the public good, but their own interests. However, participants are of diverse ethnic origin, so some exclusive networks still generate social capital across ethnic groups. Whereas from the perspective of Putnam's [12] "civicness" they produce bad social capital, from the perspective of social capital, they are producing cross-ethnic social relationships. Cross-ethnic social capital has its negative externalities and can also work to the disadvantage of the overall social capital.

In the communities where one ethnic group dominates, business owners might not have an interest or the need to employ a member of the minority community. Another possibility for minorities is to start a private business. Even in this case, a member of a minority community can face hindrances due to the language barrier and potentially limiting access to the majority population, as was the case with the pastry-factory owner in Gračanica or the Serbian business owner who was asked not to sell in an Albanian-populated village.

When the majority population refuses to cooperate and employ a minority, the majority still have a vast market of goods and workforce within their ethnic group available to them. Exclusive business networks may impose disadvantageous consequences to business owners and unemployed individuals from minority groups. Refusal to employ minorities is reinforcing minorities' disadvantaged social and economic position. The prevalence of bonding relationships obstructs the economic inclusion of minorities.

For example, a Serbian minority residing in Albanian-dominated communities in Kosovo or an Albanian minority living in Serb-dominated areas that are compelled to seek employment only in firms owned by minorities encounter more problems in the labour market than an unemployed individual from the majority population. Discrimination disrupts the inclusion of minorities in the labour market, thus hindering their social integration.

Awareness of the disapproval of cross-ethnic partnerships, as a form of social control and keeping the distance with the outsiders, instigates hidden networking. This particular occurrence was reported in the interviews in Kosovo. The interviewed experts stated that people are afraid that cooperation between Albanians and Serbs might be perceived negatively in the context of political disputes between Kosovo and Serbia (Interview 3). There is still residual distrust and resentment between ethnic groups (Interview 2). Interviewees agree that entrepreneurs are reluctant to involve publicly in cross-ethnic business partnerships. Some entrepreneurs would rather hide cross-ethnic cooperation from the community to avoid judgment, stated Interviewee No. 1.

Pressures for conformity and exclusion of different ethnic groups encourage avoiding cooperation or concealing cooperation with the discriminated ethnic groups. Another reason that entrepreneurs hide cross-ethnic business cooperation in Kosovo could be that it is not recognised as an acceptable model of a business venture. Business relationships 
propagate social closeness with the other ethnic group. Hence, entrepreneurs avoid announcing it to escape the judgement that could jeopardise their business if it is exposed. The disapproval goes both ways, either the Albanian community condemns their members for working with Serbs, or vice versa.

To avoid judgment from the community and uphold the conformity standards that entail the exclusion of other ethnic groups from social interaction, entrepreneurs in Kosovo might hide their cross-ethnic business cooperation. While in $\mathrm{BiH}$, an entrepreneur may proclaim his cross-ethnic business, in Kosovo, some prefer to conceal such tendencies. The business relationship between Albanians and Serbs infers that the two ethnic groups encourage and support each other.

From the perspective of the social significance of bridging relationships, we elaborate on their strength. Bridging relationships between entrepreneurs correspond to weak ties at the beginning of the relationship. Entrepreneurs' weak ties become stronger as the relationship evolves. Weak business ties that are maintained over time and planned for the future challenge the "weakness" of weak ties.

Maintained business cooperation brings a positive outcome to participants in business networks that over time becomes warm, even friendly. However, as entrepreneurs initiate business relationships outside of the family, and a circle of close friends, such relationships are instantly defined as weak ties. Business sociability arising from weak ties contests their weakness. Long-lasting business relationships where business owners have regular, frequent, and trustworthy interactions could be interpreted as strong ties.

Weak business ties upheld through regular and frequent interaction could be interpreted as strong-weak ties. Reciprocity and trust have a major role in turning relationships from weak to strong. The possibly emotional basis is missing, but the commitment and reciprocity embedded in the long-lasting and trustworthy business relationship resemble strong ties. Therefore, it may not be accurate to define them as weak, because there are certain circumstances when they act as strong ties. These strong-weak ties connect ethnically diverse networks and produce the channel for exchange not only in the area of business but also in social and personal communication.

\section{Conclusions}

The contribution of this article is three-fold, first, to emphasising the role of business cooperation and employment in bridging divided ethnic groups, second, emancipating the concept of social capital in the business, and third, highlighting the advantageous aspects of relationships between ethnic groups that took place after the bloodshed wars in the Western Balkans.

The empirical results demonstrate that entrepreneurs of different ethnic backgrounds cooperate. Business owners highly regard proper qualifications notwithstanding the employee's ethnic background. Entrepreneurs cross ethnic boundaries to enhance business opportunities. In that process, they create and facilitate social capital.

The social capital created in business primarily serves firms and customers, but at the same time also their communities. Social capital originating from business relations is incorporated into the overall societal social capital. Social values generated through business enable tolerant relations in post-conflict societies. Hence, entrepreneurs' social capital restores broken ethnic relations in societies torn by ethnic divisions.

Although selfish impetus is behind entrepreneurs' commercial endeavours, the facilitation of social capital transpires across ethnic communities. Confining social capital to civil relations overlooks the role of entrepreneurs as social facilitators. With entrepreneurs mobility across business, personal and social networks, accumulated social capital is also mobile. Entrepreneurs diffuse beneficial social values, norms, and customs among ethnic groups, thus generating social cohesiveness.

The lack of data on bridging and bonding social capital in business in the post-conflict Western Balkans placed certain constraints in the preparation of this study. Insufficient studies on business relations across ethnic lines and their effect on social capital in the 
post-conflict societies in the Western Balkans was an obstacle during the research, but also revealed untapped sources for exploring relationships between ethnic groups from the perspective of cooperation and collective action.

Our suggestions for future research are to examine the bridging and bonding relationships from the perspective of ethnicity, race, and religion. This approach could raise new questions concerning economic integration and social capital building in ethnically divided societies utilised for the advancement of socio-political circumstances in fragile states. Studying cooperative behaviour among divided ethnic groups in culture, sports, and associations could deepen the concept of social spillovers across various sectors.

The societal division may be more distinctive in the cases of escalated conflicts in ethnically divided societies, but divergences also exist in societies with the diverse ethnic structure of the indigenous population. Studying patterns of cross-ethnic cooperation in peaceful communities and comparing them to the cooperation patterns in post-conflict societies could advance knowledge about factors that are determinant in sustaining affirmative cross-ethnic relations.

We highlight the potential of cross-ethnic business networks in the facilitation of social capital as a new perspective on the process of reconciliation and peacebuilding. Research on ethnically diverse business and social networks could be extended to the further advancement of sustainable economic development. Therefore, innovative and inclusive approaches to restoring ethnic relations in divided post-conflict societies entail a comprehensive understanding of the social and economic processes at the local level and determining the capacity of purposeful cross-ethnic interaction. Our results support the conclusion that introducing public policies that would replace the current institutionalisation of ethnic segregation and promote cooperation in the social, economic, and political spheres, is a necessary prerequisite for sustainable peace and development in the Western Balkans.

Author Contributions: Conceptualization, A.K.; methodology, A.K.; validation, A.K.; formal analysis, A.K.; investigation, A.K.; resources, A.K.; writing—original draft preparation, A.K.; writingreview and editing, A.K., H.W.; visualization, A.K.; supervision, H.W.; project administration, A.K.; funding acquisition, A.K. All authors have read and agreed to the published version of the manuscript.

Funding: This research was funded by Open Society Foundations.

Institutional Review Board Statement: Not applicable.

Informed Consent Statement: Not applicable.

Data Availability Statement: The data presented in this study are available on request from the corresponding author.

Acknowledgments: Our greatest gratitude is owed to Florian Bieber, for the valuable guidance and consideration he offered as supervisor to Ana Kopren in planning and organizing this research project during her doctoral studies. Ana Kopren would like to offer her thankfulness to Julija Vitanova for assisting in accessing several entrepreneurs in North Macedonia. Ermina Ramić is appreciated for her support in establishing contacts in Bosnia and Herzegovina. She is immensely indebted to entrepreneurs who participated in the survey. Her gratitude is offered to professionals who took the time to share their opinion in interviews.

Conflicts of Interest: The authors declare no conflict of interest. The funders had no role in the design of the study; in the collection, analyses, or interpretation of data; in the writing of the manuscript, or in the decision to publish the results.

\section{References}

1. Eriksen, H.T. Ethnicity and Nationalism: Anthropological Perspectives, 1st ed.; Pluto Press: London, UK, 1993.

2. Van Dyke, V. The individual, the state, and ethnic communities in political theory. World Politics 1977, 29, 343-369. [CrossRef]

3. Barth, F. Ethnic groups and boundaries: The social organization of culture difference. Geogr. Rev. 1972, 62, 9-38. [CrossRef]

4. Ramet, S. The dissolution of Yugoslavia: Competing narratives of resentment and blame. Südost Eur. 2007, 55, 26-69. 
5. Bieber, F. Bosnia-Herzegovina and Lebanon: Historical lessons of two multireligious states. Third World Q. 2000, $21,269-281$. [CrossRef]

6. Žagar, M. Diversity management. Evolution of concepts. In Treaties and Documents No. 52; Brezigar, S., Lavskis, P., Solem, E.K., Žagar, M., Eds.; Institute of Ethnic Studies: Ljubljana, Slovenia, 2007; pp. 6-38.

7. Bieber, F. Partial Implementation, Partial Success: The Case of Macedonia. In New Challenges to Power-sharing: Institutional and Social Reform in Divided Societies; O'Flynn, I., Russell, D., Eds.; Pluto: London, UK, 2005; pp. 107-122. [CrossRef]

8. Colletta, N.J.; Cullen, M.L. The Nexus between Violent Conflict, Social Capital and Social Cohesion: Case Studies from Cambodia and Rwanda; Social Capital Initiative Working Paper 23; World Bank: Social Development Department: Washington, DC, USA, 2000.

9. Fukuyama, F. Social capital and development: The coming agenda. SAIS Rev. 2002, 22, 23-37. [CrossRef]

10. Granovetter, M.S. The strength of weak ties. Am. J. Sociol. 1973, 78, 1360-1380. [CrossRef]

11. Allport, W.G. The Nature of Prejudice; Perseus Publishing: New York, NY, USA, 1954.

12. Putnam, R.D.; Leonardi, R.; Nanetti, R.Y. Making Democracy Work: Civic Traditions in Modern Italy; Princeton University Press: Princeton, NJ, USA, 1993.

13. Coleman, J.S. Social capital in the creation of human capital. Am. J. Sociol. 1988, 94, S95-S120. [CrossRef]

14. Bourdieu, P. The social space and the genesis of groups. Theory Soc. 1985, 14, 723-744. [CrossRef]

15. Bourdieu, P. Forms of capital. In Handbook of Theory and Research for the Sociology of Education; Richards, C.J., Ed.; Green-Wood Press: New York, NY, USA, 1986; pp. 241-258.

16. Putnam, R.D. Bowling Alone-The Collapse and Revival of American Community; Simon and Schuster: New York, NY, USA, 2000. [CrossRef]

17. Ostrom, E.; Ahn, T.K. Introduction. In Foundations of Social Capital; Ostrom, E., Ahn, T.K., Eds.; Edward Elgar Publishing Limited: Cheltenham, UK, 2003; pp. xi-xxxix.

18. Woolcock, M.; Narayan, D. Social capital: Implications for development theory, research, and policy. World Bank Res. Obs. 2000, 15, 225-249. [CrossRef]

19. Westlund, H. Implications of Social Capital for Business in the Knowledge Economy. In Proceedings of the International Forum on Economic Implication of Social Capital, Tokyo, Japan, 24-25 March 2003; Economic and Social Research Institute Cabinet Office: Tokyo, Japan, 2003.

20. Fukuyama, F. Trust: The Social Virtues and the Creation of Prosperity; Free Press: New York, NY, USA, 1995. [CrossRef]

21. Witt, P. Entrepreneurs' networks and the success of start-ups. Entrep. Reg. Dev. 2004, 16, 391-412. [CrossRef]

22. Dakhli, M.; De Clercq, D. Human capital, social capital, and innovation: A multi-country study. Entrep. Reg. Dev. 2004, 16, 107-128. [CrossRef]

23. Portes, A. Social capital: Its origins and applications in modern sociology. Annu. Rev. Sociol. 1998, 24, 1-24. [CrossRef]

24. OECD. The Well-Being of Nations: The Role of Human and Social Capital; OECD Publications: Paris, France, 2001.

25. Westlund, H. Social capital and regional development: Research achievements and remaining problems. Ital. J. Reg. Sci. 2012, 11, $7-22$.

26. Healy, T. The Measurement of Social Capital at International Level. In Proceedings of the International Conference on the Measurement of Social Capital, London, UK, 25-27 September 2002; Available online: http://www.oecd.org/innovation/ research/2380281.pdf (accessed on 6 February 2021).

27. Westlund, H.; Bolton, R. Local social capital and entrepreneurship. Small Bus. Econ. 2003, 21, 77-113. [CrossRef]

28. Westlund, H.; Nilsson, E. Measuring enterprises' investments in social capital: A pilot study. Reg. Stud. 2005, 39, 1079-1094. [CrossRef]

29. Glaeser, E.; Laibson, D.; Sacerdote, B. An Economic Approach to Social Capital. Econ. J. 2002, 112, 437-458. [CrossRef]

30. Westlund, H.; Larsson, J.P. Social capital and regional development: An introduction. In Handbook of Social Capital and Regional Development; Wesltund, H., Larsson, J.P., Eds.; Edward Elgar Publishing: London, UK, 2016; pp. 1-23. [CrossRef]

31. Putnam, D.R.; Feldstein, M.L. Better Together: Restoring the American Community; Simon and Schuster: New York, NY, USA, 2004.

32. Poulsen, A.; Svendsen, G.T. Love Thy Neighbour: Bonding Versus Bridging Trust; Working Paper 05-7; University of Aarhus, Aarhus School of Business, Department of Economics: Aarhus, Denmark, 2005.

33. Wollebaek, D.; Lundåsen, S.W.; Trägårdh, L. Three forms of interpersonal trust: Evidence from Swedish municipalities. Scand. Political-Stud. 2012, 35, 319-346. [CrossRef]

34. Pickering, P.M. Generating social capital for bridging ethnic divisions in the Balkans: Case studies of two Bosniak cities. Ethn. Racial Stud. 2006, 29, 79-103. [CrossRef]

35. Pieterse, J.N. Social capital and migration: Beyond ethnic economies. Ethnicities 2003, 3, 29-58. [CrossRef]

36. Tolciu, A. Migrant entrepreneurs and social capital: A revised perspective. Int. J. Entrep. Behav. Res. 2011, 17, 409-427. [CrossRef]

37. Goyal, S. Connections: An Introduction to the Economics of Networks; Princeton University Press: Princeton, NJ, USA, 2007.

38. Lechner, C.; Dowling, M. Firm networks: External relationships as sources for the growth and competitiveness of entrepreneurial firms. Entrep. Reg. Dev. 2003, 15, 1-26. [CrossRef]

39. Van Der Leij, M.; Goyal, S. Strong ties in a small world. Rev. Netw. Econ. 2011, 10, 1-22. [CrossRef]

40. Aldrich, H.; Zimmer, C. Entrepreneurship through social networks. In The Art and Science of Entrepreneurship; Sexton, D., Smilor, D., Eds.; Ballinger Press: Cambridge, MA, USA, 1986; pp. 3-24.

41. Katz, N.; Lazer, D.; Arrow, H.; Contractor, N. Network theory and small groups. Small Group Res. 2004, 35, 307-332. [CrossRef] 
42. Drakopoulou, D.S.; Keles, J.Y. Expanding the Networks of Disadvantaged Entrepreneurs. A Background Paper for the OECD Centre for Entrepreneurship, SMEs and Local Development. 2014. Available online: https:/ /www.researchgate.net/publication/ 275659239_Expanding_the_networks_of_disadvantaged_entrepreneurs (accessed on 6 February 2021).

43. Friedkin, N. A test of structural features of Granovetter's strength of weak ties theory. Soc. Netw. 1980, 2, 411-422. [CrossRef]

44. Marin, A.; Mitchell, R.K.; Lee, J.H. The vulnerability and strength duality in ethnic business: A model of stakeholder salience and social capital. J. Bus. Ethic. 2015, 130, 271-289. [CrossRef]

45. World Economic Forum. The Global Competitiveness Report 2016/2017; World Economic Forum: Geneva, Switzerland, 2018; Available online: http:/ / www3.weforum.org/docs/GCR2016-2017/05FullReport/TheGlobalCompetitivenessReport2016-20 17_FINAL.pdf (accessed on 17 March 2021).

46. European Investment Bank. Assessment of Financing Needs of SMEs in the Western Balkan Countries: Country Report Macedonia; EIB: London, UK, 2016; Available online: https:/ / www.eib.org/attachments/efs/assessment_of_financing_needs_of_smes_fyrom_en. pdf (accessed on 10 March 2021).

47. Camaj, L. Media Use and Political Trust in an Emerging Democracy: Setting the Institutional Trust Agenda in Kosovo. Int. J. Commun. 2014, 8, 187-209.

48. Malazogu, L.; Kllokoqi, S. Translation of Trust: Perception of Representation and Participation; Series: Elections 6; Democracy for Development Institute: Priština, Kosovo, 2013.

49. UNDP. The Ties that Bind: Social Capital in Bosnia and Herzegovina; National Human Development Report; UNDP: Sarajevo, Bosnia and Herzegovina, 2009; Available online: http://hdr.undp.org/sites/default/files/bosnia_nhdr_2009_en_0.pdf (accessed on 10 March 2021).

50. Marković, N.; Damjanovski, I. The uncharted political realm—social capital, political values and practices stimulating informal networks in Macedonia. New Balk. Politics 2015, 17, 10-19.

51. Håkansson, P.; Sjöholm, F. Who do you trust? Ethnicity and trust in Bosnia and Herzegovina. Eur. Stud. 2007, 59, 961-976. [CrossRef]

52. Håkansson, P.; Hargreaves, S. Trust in Transition: Generalised Trust in Bosnia and Herzegovina; Balkan Analysis Group: Sarajevo, Bosnia and Herzegovina, 2004; Available online: https:/ / portal.research.lu.se/ws / files/5677105/1388890.pdf (accessed on 16 March 2021).

53. Klekovski, S.; Nuredinoska, E.; Stojanova, D. Trust in Macedonia: General Trust and Trust in Institutions, Trust in Civil Society, Knowledge and Opinion about Civil Society Organization; Macedonian Center for International Cooperation: Skopje, North Macedonia, 2010.

54. Centre for Social Research Analitika. Survey Results: A High Degree of Distrust in Political Parties and Government Institutions in Bosnia and Herzegovina; Centre for Social Research Analitika: Sarajevo, Bosnia and Herzegovina, 2014; Available online: https:/ / www.analitika.ba/sites/default/files/publikacije/povjerenje_fact_sheet_english.pdf (accessed on 17 March 2021).

55. Riinvest Institute. Improving the Kosovo Serbian Business Community Involvement in Economic Activities in Kosovo; Riinvest Institute: Priština, Kosovo, 2012; Available online: https:/ / www.riinvestinstitute.org/uploads/files/2016/October/17/imp-eng_en14766 94919.pdf (accessed on 17 March 2021). 